\title{
The GDP-GTP Exchange Factor Collybistin: An Essential Determinant of Neuronal Gephyrin Clustering
}

\author{
Kirsten Harvey, ${ }^{1}$ Ian C. Duguid, ${ }^{2 \star}$ Melissa J. Alldred, ${ }^{3 \star}$ Sarah E. Beatty, ${ }^{4}$ Hamish Ward, ${ }^{4}$ Nicholas H. Keep, ${ }^{5}$ \\ Sue E. Lingenfelter, ${ }^{3}$ Brian R. Pearce, ${ }^{1}$ Johan Lundgren, ${ }^{6}$ Michael J. Owen, ${ }^{7}$ Trevor G. Smart, ${ }^{2}$ Bernhard Lüscher, ${ }^{3}$ \\ Mark I. Rees, ${ }^{4,8}$ and Robert J. Harvey ${ }^{1}$ \\ ${ }^{1}$ Department of Pharmacology, The School of Pharmacy, London WC1N 1AX, United Kingdom, ${ }^{2}$ Department of Pharmacology, University College London, \\ London WC1E 6BT, United Kingdom, ${ }^{3}$ Department of Biology and Department of Biochemistry and Molecular Biology, Pennsylvania State University, \\ University Park, Pennsylvania 16802, ${ }^{4}$ Department of Molecular Medicine, Faculty of Medical and Health Sciences, University of Auckland, Private bag \\ 92019, Auckland, New Zealand, ${ }^{5}$ School of Crystallography, Birkbeck, University of London, London WC1E 7HX, United Kingdom, ${ }^{6}$ Department of \\ Pediatrics, University Hospital, SE-221 85 Lund, Sweden, ${ }^{7}$ Psychological Medicine, University of Wales College of Medicine, Cardiff CF14 4XN, United \\ Kingdom, and ${ }^{8}$ Swansea Clinical School, University of Wales, Swansea SA2 8PP, United Kingdom
}

Glycine receptors (GlyRs) and specific subtypes of $\mathrm{GABA}_{\mathrm{A}}$ receptors are clustered at synapses by the multidomain protein gephyrin, which in turn is translocated to the cell membrane by the GDP-GTP exchange factor collybistin. We report the characterization of several new variants of collybistin, which are created by alternative splicing of exons encoding an N-terminal $s r c$ homology 3 (SH3) domain and three alternate $\mathrm{C}$ termini ( $\mathrm{CB} 1, \mathrm{CB} 2$, and $\mathrm{CB} 3$ ). The presence of the $\mathrm{SH} 3$ domain negatively regulates the ability of collybistin to translocate gephyrin to submembrane microaggregates in transfected mammalian cells. Because the majority of native collybistin isoforms appear to harbor the SH3 domain, this suggests that collybistin activity may be regulated by protein-protein interactions at the SH3 domain. We localized the binding sites for collybistin and the GlyR $\beta$ subunit to the C-terminal MoeA homology domain of gephyrin and show that multimerization of this domain is required for collybistin-gephyrin and GlyR-gephyrin interactions. We also demonstrate that gephyrin clustering in recombinant systems and cultured neurons requires both collybistin-gephyrin interactions and an intact collybistin pleckstrin homology domain. The vital importance of collybistin for inhibitory synaptogenesis is underlined by the discovery of a mutation (G55A) in exon 2 of the human collybistin gene (ARHGEF9) in a patient with clinical symptoms of both hyperekplexia and epilepsy. The clinical manifestation of this collybistin missense mutation may result, at least in part, from mislocalization of gephyrin and a major $\mathrm{GABA}_{\mathrm{A}}$ receptor subtype.

Key words: dendritic transport; epilepsy; $\mathrm{GABA}_{\mathrm{A}}$ receptor; glycine receptor; hyperekplexia; trafficking

\section{Introduction}

Inhibitory neurotransmission relies on glycine and GABA receptors being clustered at postsynaptic specializations opposite axon terminals releasing the corresponding neurotransmitters. Central to this arrangement is gephyrin, which colocalizes with glycine receptors (GlyRs) at inhibitory synapses (Triller et al., 1985; Schmitt et al., 1987). Gephyrin can interact with polymerized tubulin (Kirsch et al., 1991), the GlyR $\beta$ subunit (Kneussel et al., 1999a), profilin (Mammoto et al., 1998), RAFT-1 (rapamycin and FKBP target-1) (Sabatini et al., 1999), dynein light chains 1 and 2 (Fuhrmann et al., 2002), and Mena (mammalian enabled)/

\footnotetext{
Received Nov. 25, 2003; revised May 12, 2004; accepted May 13, 2004.

This work was supported by grants from the Medical Research Council (United Kingdom) to R.J.H. and T.G.S., the Neurological Foundation for New Zealand and Auckland Medical Research Foundation to M.I.R., and National Institute of Mental Health (MH62391) to B.L. We thank Helena de Silva for HEK293 cell culture and transfections and Dr. Jean-Marc Fritschy for the generous gift of $\mathrm{ABBA}_{A}$ receptor antisera.

*I.C.D. and M.J.A. contributed equally to this work.

Correspondence should be addressed to RobertJ. Harvey, Department of Pharmacology, The School of Pharmacy,

29-39 Brunswick Square, London WC1N 1AX, United Kingdom. E-mail: robert.harvey@ulsop.ac.uk. D0I:10.1523/JNEUROSCI.1184-04.2004

Copyright $\odot 2004$ Society for Neuroscience $\quad 0270-6474 / 04 / 245816-11 \$ 15.00 / 0$
}

VASP (vasodilator stimulated phosphoprotein) (Giesemann et al., 2003). In addition, gephyrin is also essential for the postsynaptic clustering of $\mathrm{GABA}_{\mathrm{A}}$ receptors containing $\alpha 2$ or $\alpha 3$ subunits (Essrich et al., 1998; Kneussel et al., 1999b, 2001b; Levi et al., 2004). A selective loss of synaptic $\mathrm{GABA}_{\mathrm{A}}$ receptors in $\gamma 2$ subunit mutant mice also results in the loss of gephyrin clusters (Essrich et al., 1998; Schweizer et al., 2003), indicating some interdependence for their synaptic localization. Interestingly, when expressed in mammalian cells, gephyrin forms cytoplasmic aggregates (Kirsch et al., 1995), suggesting that other "factors" are required to direct gephyrin to submembrane microaggregates. The preliminary characterization of collybistin (Kins et al., 2000; Grosskreutz et al., 2001), a novel gephyrin-associated GDP-GTP exchange factor (GEF), presented a plausible mechanism(s) by which gephyrin could be targeted to synapses.

Collybistin is a member of the guanine nucleotide exchange factor superfamily, which catalyzes GDP-GTP exchange on small GTPases of the Rho family (Wherlock and Mellor, 2002). GEFs are characterized by tandem exchange factor (RhoGEF) and pleckstrin homology $(\mathrm{PH})$ domains. The RhoGEF domain catalyzes the exchange reaction, whereas the $\mathrm{PH}$ domain can bind 
with high affinity to membrane phosphoinositides, thus restricting GEF localization and activity to the submembrane compartment (Kavran et al., 1998). Collybistin was initially found in two isoforms created by alternative splicing: "collybistin I," which contains an N-terminal src homology 3 (SH3) domain and a C-terminal coiled-coil domain, and "collybistin II," which lacks the $\mathrm{SH} 3$ domain and has an alternate $\mathrm{C}$ terminus. On expression in human embryonic kidney (HEK) 293 cells, collybistin I colocalized with intracellular gephyrin aggregates, whereas collybistin II enabled translocation of gephyrin to submembrane microaggregates (Kins et al., 2000). The human homolog of collybistin, hPEM-2 (human homolog of Posterior End Mark-2), appears to activate the GTPase Cdc42 (Reid et al., 1999), which influences cell morphology by initiating actin cytoskeleton remodeling (Erickson and Cerione, 2001). It has been proposed that at inhibitory synapses, collybistin initiates local remodeling of the subsynaptic cytoskeleton (Kneussel and Betz, 2000).

In this study, we investigated the diversity of collybistin isoforms generated by alternative splicing and the role of the $\mathrm{SH} 3$, RhoGEF, and PH domains in translocating gephyrin to submembrane microaggregates. We also mapped the binding sites for collybistin and the GlyR $\beta$ subunit on gephyrin. This information was used to evaluate ARHGEF9 as a candidate gene for hyperekplexia in a cohort of 32 patients without mutations in the GlyR $\alpha 1$ and $\beta$ subunit genes or gephyrin (Rees et al., 2001, 2002, 2003). Examination of naturally occurring and artificial mutants of collybistin emphasizes the importance of this RhoGEF for postsynaptic localization of gephyrin and inhibitory ligand-gated ion channels.

\section{Materials and Methods}

Amplification, cloning, and sequencing of rat and human collybistin cDNAs. Rat collybistin cDNAs were amplified from postnatal day $(\mathrm{P}) 0$ rat spinal cord and whole-brain first-strand cDNA using the primer combinations $\mathrm{r} 1$ : 5'-GTGGGATCCATGCAGTGGATTAGAGGCGGA-3' plus r2: 5' -TTCGAATTCCCCATCCTCCTGGTTCACCCA-3' and r $35^{\prime}$-GGAGGATCCAATACGTTGGCTTAGAGCTTT-3' plus r4 5' -TTAGAATTCTCTGCCTTCCTATAGGTATTA-3'. Human collybistin cDNAs were amplified from human whole-brain or spinal cord cDNA (Clontech, Cambridge, UK) using the primer combinations h1: 5'-CATGGCCTCGCTGTGATATGTATG-3' plus h2: 5' -TCCAGGTGTCCGTTCTGCACATCG-3' or h3 5'-CTGCAATGACTGTGAGAAAAGTCC-3' plus h4 $5^{\prime}$-ATTATCTGCCTCCCTGTAGGTATC- ${ }^{\prime}$. Amplifications were performed under semiquantitative conditions using $P f u$ Turbo proofreading DNA polymerase (Stratagene, La Jolla, CA) and 30 cycles of $94^{\circ} \mathrm{C}$ for 1 min, $65^{\circ} \mathrm{C}$ for $1 \mathrm{~min}$, and $68^{\circ} \mathrm{C}$ for $3 \mathrm{~min}$. PCR products were cloned into the pCR4 Blunt TOPO vector (Invitrogen, San Diego, CA), and plasmid DNAs were made using spin miniprep and maxi kits (Qiagen, Hilden, Germany). Plasmid inserts were fully sequenced using the BigDye ready reaction mix (PerkinElmer Life Sciences, Emeryville, CA) and an Applied Biosystems (Foster City, CA) 310 automated DNA Sequencer.

Functional assays of collybistin-gephyrin interactions in HEK293 cells. $p R K 5 m y c-C B 2_{\mathrm{SH}_{3}+}, \mathrm{pRK} 5 \mathrm{myc}-\mathrm{CB} 2_{\mathrm{SH}_{3}-}$, and $\mathrm{pRK} 5 \mathrm{myc}-\mathrm{CB} 3_{\mathrm{SH}_{3}-}$ : collybistin cDNAs were amplified from P0 rat brain first-strand cDNA using the primers $\mathrm{r} 1$ and $\mathrm{r} 4$ (see above) and cloned into the BamHI and EcoRI sites of the vector pRK5myc so that a 9E10 (myc) tag is attached to the $\mathrm{N}$ terminus. Deletions of the $\mathrm{SH} 3, \mathrm{RhoGEF}$, and $\mathrm{PH}$ domains were made in $p R K 5 m y c-C B 2_{S H 3}-$ using the Quikchange site directed mutagenesis kit (Stratagene). $p E G F P$-gephyrin: the entire coding region of the rat gephyrin P1 isoform (Prior et al., 1992) was amplified from P0 rat brain firststrand cDNA using the primers rGeph1 5'-CGCTGATCAACATGGCGACCGAGGGA-3' and rGeph2 5'-TGGCTCGAGTCATAGCCGTCCGATGA- $3^{\prime}$, cut with BclI and XhoI, and cloned into the BglII and Sall sites of pEGFP-C2 (Clontech), so that the enhanced green fluorescent protein (EGFP) tag is $\mathrm{N}$ terminal. $p D s R e d-G l y R \beta$ : the large intracellular loop of the human GlyR $\beta$ subunit (Handford et al., 1996) was amplified using the primers $\mathrm{h} \beta$ DsRed 1 5'-GCTGAATTCGCCACCATGGCAGTTGTCCAGGTGATGCT- $3^{\prime}$ and h $\beta$ DsRed 2 5'-AACGGATCCCTTGCATAAAGATCAATTCGC-3' and cloned into the EcoRI and BamHI sites of pDSRedN1 (Clontech), so that the DsRed tag is $\mathrm{C}$ terminal. Amplifications were performed using Pfu Turbo DNA polymerase, and all plasmids were sequenced to confirm the veracity of the constructs. HEK293 cells (CRL1573; American Type Culture Collection, Manassas, VA) were grown in DMEM supplemented with $10 \%(\mathrm{v} / \mathrm{v})$ fetal bovine serum (FBS), $2 \mathrm{~mm}$ glutamine, $100 \mathrm{U} / \mathrm{ml}$ penicillin $\mathrm{G}$, and 100 $\mu \mathrm{g} / \mathrm{ml}$ streptomycin at $37^{\circ} \mathrm{C}$ in $95 \%$ air $-5 \% \mathrm{CO}_{2}$ (Harvey et al., 1999). Exponentially growing cells were electroporated ( $400 \mathrm{~V}$; infinite resistance, $125 \mu \mathrm{F}$; Gene Electropulser II; Bio-Rad, Hercules, CA) with various combinations of the plasmid constructs. For cotransfections (e.g., myc-CB2 ${ }_{\mathrm{SH} 3}-$ plus EGFP-gephyrin), plasmids were used at a ratio of 1:1. After $24 \mathrm{hr}$, cells were washed twice in PBS and fixed for $5 \mathrm{~min}$ in $4 \%$ $\left(\right.$ w/v) paraformaldehyde (PFA) in PBS. Myc-tagged $\mathrm{CB}_{\mathrm{SH}_{3}+}, \mathrm{CB}_{\mathrm{SH}_{3}-}$, and $\mathrm{CB}_{\mathrm{SH} 3}$ proteins were detected using an anti-9E10 monoclonal antibody (mAb) (Sigma, St. Louis, MO) and tetramethylrhodamine isothiocyanate- or cyanin 5 (Cy5)-conjugated secondary antibodies (Jackson ImmunoResearch, West Grove, PA) using standard protocols. Confocal microscopy was performed as described previously (Dunne et al., 2002).

Culture, transfection, and immunostaining of cortical neurons. Cortical neurons were cultured from embryonic day (E) 14 mice. Cortical hemispheres were collected in PBS, pH 7.4, containing $5.5 \mathrm{~mm}$ glucose and treated with papain $(0.5 \mathrm{mg} / \mathrm{ml}$; Sigma $)$ and DNase I $(10 \mu \mathrm{g} / \mathrm{ml})$ in PBS containing $1 \mathrm{mg} / \mathrm{ml}$ bovine serum albumin and $10 \mathrm{~mm}$ glucose for $15 \mathrm{~min}$ at room temperature. The cells were mechanically triturated and then plated on poly-L-lysine-coated glass coverslips at $4 \times 10^{4} \mathrm{cells} / \mathrm{cm}^{2}$ in modified Eagle medium (Invitrogen) containing 10\% (v/v) FBS, which was replaced after $60 \mathrm{~min}$. After $24 \mathrm{hr}$, the coverslips were turned upside down onto a glial feeder layer in a Petri dish containing Neurobasal-A supplemented with B27 (Invitrogen). Neurons were transfected at $18 \mathrm{~d}$ in vitro (DIV) using a calcium coprecipitation transfection kit (BD Biosciences, Palo Alto, CA). Briefly, the coverslips were reinverted and transferred into new Petri dishes containing glia-conditioned Neurobasal A/B27 supplemented with $0.8 \mathrm{mg} / \mathrm{ml} \mathrm{NaHCO}_{3}, 1 \mu \mathrm{M}$ 6-cyano-7nitoquinoxaline-2,3-dione (Sigma), and $100 \mu \mathrm{M}$ 2-amino-5-phosphonovaleric acid (Sigma). Plasmid DNA (10 $\mu \mathrm{g} /$ coverslip) was mixed with $12.4 \mu \mathrm{l}$ of $2 \mathrm{M} \mathrm{CaCl}_{2}$ to a final volume of $100 \mu \mathrm{l}$ and then added slowly to an equal volume of $2 \times$ HEPES-buffered saline while thoroughly mixing. The DNA was allowed to precipitate for $15 \mathrm{~min}$, added to the cells, and incubated for $45 \mathrm{~min}$. The coverslips were then returned to the original dishes containing conditioned medium and used for immunocytochemistry at $21 \mathrm{DIV}$.

Neurons on coverslips were rinsed with PBS, fixed with $4 \%$ (w/v) PFA in $150 \mathrm{~mm}$ sodium phosphate buffer, $\mathrm{pH}$ 7.4, for $15 \mathrm{~min}$, permeabilized for 5 min with $0.15 \%$ saponin in PBS containing $10 \%(\mathrm{v} / \mathrm{v})$ normal donkey serum, and incubated overnight at $4^{\circ} \mathrm{C}$ with combinations of primary antibody to the myc tag of collybistin constructs (rabbit polyclonal anti-Myc Tag; Medical and Biological Laboratories, Nahgoya, Japan), gephyrin (mAb7a; Alexis Biochemicals, San Diego, CA), or glutamic acid decarboxylase (mAb GAD-6; Developmental Studies Hybridoma Bank, University of Iowa, Iowa City, IA) and the GABA receptor $\gamma 2$ subunit (raised in guinea pigs) (Fritschy and Mohler, 1995) in PBS containing $0.15 \%(\mathrm{v} / \mathrm{v})$ saponin and $10 \%(\mathrm{v} / \mathrm{v})$ normal donkey serum. Note that for experiments with EGFP-gephyrin constructs, $\mathrm{mAb} 7 \mathrm{a}$ is assumed to recognize both native and recombinant gephyrin. The cells were washed in PBS containing $0.15 \%(\mathrm{v} / \mathrm{v})$ saponin and then incubated with secondary antibody raised in the proper species and conjugated to AlexaFluor 488 (Molecular Probes, Eugene, OR), Cy3, or Cy5 (Jackson ImmunoResearch) in PBS containing $0.15 \%$ (v/v) saponin and $10 \%(\mathrm{v} / \mathrm{v})$ normal donkey serum. Epifluorescent images were captured using a Zeiss (Thornwood, NY) Axiophot2 microscope equipped with a 1.3 differential interference contrast $40 \times$ objective and an ORCA-100 cooled CCD camera linked to an Openlab imaging system (Improvision, Lexington, MA).

Quantitation of immunofluorescence images. To quantify the effects of transfecting wild-type or mutant collybistin and gephyrin constructs into 
neurons, two dendritic segments of $40 \mu \mathrm{m}$ length were selected per cell (for 10-12 transfected cells per construct) that exhibited low overall background staining for gephyrin $(\mathrm{mAb} 7 \mathrm{a})$ or the $\mathrm{GABA}_{\mathrm{A}}$ receptor $\gamma 2$ subunit. Immunoreactive puncta (size range, $0.2-2 \mu \mathrm{m}$ in diameter) in each segment were automatically selected by setting a fluorescence intensity threshold that was twofold greater than the diffuse fluorescence on dendritic shafts within the region of interest. The average number of gephyrin ( $\mathrm{mAb} 7 \mathrm{a})$ clusters was determined by counting the number of immunoreactive puncta within the correct size range per $40 \mu \mathrm{m}$ segment per cell. The number of $\mathrm{GABA}_{\mathrm{A}}$ receptor clusters (punctate $\gamma 2$ immunoreactivity) was determined identically on dendritic segments that were innervated by GABAergic terminals (as judged by GAD staining). Analysis was performed using Openlab imaging software with Microsoft (Seattle, WA) Excel. Student's two-tailed $t$ test was used for all statistical comparisons.

Mapping binding sites on gephyrin using the GAL4 yeast two-hybrid system. To identify putative domains of gephyrin, which interact with the collybistin and the GlyR $\beta$ subunit, several baits were cloned into the GAL4 binding domain vector pYTH9, which can be integrated into the trp locus for stable expression of fusion proteins (Fuller et al., 1998). pYTH9$\mathrm{CB} 2_{\mathrm{SH}_{3}-}: \mathrm{pRK} 5 \mathrm{myc}-\mathrm{CB} 2_{\mathrm{SH} 3}$ - was cut with $\mathrm{NcoI}$ and $E c o$ RI to release the full-length cDNA, and this was cloned into the corresponding sites in pYTH9.pYTH9-GlyR $\beta$ : the large intracellular loop of the human GlyR $\beta$ subunit (Handford et al., 1996) was amplified using the primers hGlyR $\beta 1$ 5'-GGTGTCGACGAACAACCCCAAAAGGGTTGA-3' and hGlyR $\beta 2$ 5'-AGGGAATTCTCATCTTGCATAAAGATCAAT-3' and cloned into the SalI and EcoRI sites of pYTH9. pYTH9-MoeA: the "MoeA homology domain" from the rat gephyrin P1 isoform (Prior et al., 1992) was amplified using the primers rGeph3 5' -AGCGTCGACCAGTGCTGTAGATATCA-3' and rGeph4 5'-TGGCCGCGGTCATAGCCGTCCGATGACCA-3' and cloned into the SalI and SacII sites of pYTH9. Fragments of the rat gephyrin $\mathrm{P} 1$ isoform cDNA were amplified using multiple oligonucleotide primers and were cloned into the vector pACT2 (Clontech). As above, amplifications were performed using $P f u$ Turbo DNA polymerase, and all constructs were fully sequenced. Cotransformed yeast were plated on selective dropout media lacking leucine and tryptophan (Clontech) and incubated at $30^{\circ} \mathrm{C}$ for 3-6 d to allow prototropic colonies to emerge. Lac Z reporter gene assays were performed as described previously (Fuller et al., 1998).

Collybistin gene structures and analysis in hyperekplexia patients. Human collybistin cDNAs (Reid et al., 1999; our study) were submitted for Basic Local Alignment Search Tool (BLAST)-like alignment tool searches of the University of California Santa Cruz Genome Browser Database (Karolchik et al., 2003) (http://genome.ucsc.edu/). Intron-exon organizations were established from comparisons of cloned cDNAs, spliced expressed sequence tags (ESTs) and genomic sequences. The majority of patients included in the mutation analysis of the human collybistin gene (ARHGEF9) are described previously (Rees et al., 2001). An additional seven unrelated hyperekplexia patients were also analyzed; all conform to the diagnostic criteria of inclusion, which involves a history of neonatal hypertonia, a nose tap response, and an exaggerated startle response leading to injurious fall down consequences with preservation of consciousness (Andrew and Owen, 1997). Exons and flanking intronic sequences, plus $5^{\prime}$ and $3^{\prime}$ untranslated regions, were amplified from patient DNAs using the primers detailed in supplemental Table 1 (available at www.jneurosci.org) (Rees et al., 2001, 2002). Each $25 \mu \mathrm{l}$ reaction contained $60 \mathrm{ng}$ of genomic DNA, $10 \mathrm{pmol}$ of each primer, $1.5 \mathrm{mM} \mathrm{MgCl}_{2}, 50$ $\mathrm{mm} \mathrm{KCl}, 10 \mathrm{~mm}$ Tris-HCl, pH 8.3, $200 \mu \mathrm{M}$ dNTPs (Amersham Biosciences, Arlington Heights, IL), and 1 U Taq polymerase (Qiagen). PCR conditions consisted of an initial denaturation at $94^{\circ} \mathrm{C}$ for $5 \mathrm{~min}$ followed by $35 \mathrm{cycles}$ of $30 \mathrm{sec}$ at $94^{\circ} \mathrm{C}, 30 \mathrm{sec}$ at $60^{\circ} \mathrm{C}$, and $30 \mathrm{sec}$ at $72^{\circ} \mathrm{C}$. Mutation analysis of PCR products was performed using Transgenomic dHPLC HT-WAVE $^{\mathrm{R}}$ DNA Fragment Analysis System, using DNASep ${ }^{\mathrm{R}}$ columns (Transgenomic, Omaha, NE). The program dHPLCMelt was used to predict the optimal melting conditions for PCR fragments, and the WAVE instrument was run under partially denaturing conditions for mutation detection and single-nucleotide polymorphism (SNP) discovery. Because of the X-linked localization of ARHGEF9, all male patient PCRs were combined with a sequence-verified female DNA control. Variant dHPLC profiles suggestive of allelic heterogeneity were gel iso- lated (Qiagen) and sequenced using ABI3100 technology. The G55A mutant was introduced into $p R K 5 m y c-C B 3_{S H 3}+$ using the Quikchange site-directed mutagenesis kit (Stratagene).

\section{Results \\ Multiple collybistin isoforms are generated by alternative splicing}

Yeast two-hybrid screening with gephyrin originally identified two collybistin isoforms, which were created by alternative splicing of primary transcripts (Kins et al., 2000). Alternative splicing of collybistin mRNAs appears to have functional relevance, because only collybistin II is able to translocate gephyrin to submembranous microaggregates (Kins et al., 2000). We performed reverse transcriptase (RT)-PCR assays from rodent-human spinal cord and whole-brain cDNAs to assess the relative abundance of different collybistin transcripts. DNA sequence analysis of both amplified and published cDNAs (Kins et al., 2000) revealed that three different collybistin $\mathrm{C}$ termini can be specified in the rat by the use of different cassette exons (Fig. 1A-D). Collybistin I (GRVGEEENQSLELKRACEVLQRLWSPGKKS ${ }^{*}$ ) and collybistin II (VTQRKWHY*) C termini are generated by insertion of either 109 or 62 bp exons into collybistin transcripts (Fig. $1 A, C$ ). When neither exon is used, a third $\mathrm{C}$ terminus is specified, which shares 59 of 60 residues with the $\mathrm{C}$ terminus of human collybistin (hPEM-2) (Reid et al., 1999). In contrast, the exon encoding the N-terminal SH3 domain is used in the majority of rodent and human collybistin brain mRNAs (Fig. $1 B$ ). Splicing of this exon did not alter during postnatal development in mouse brain (Fig. $1 B$ ).

Accordingly, we renamed these collybistin isoforms CB1 (collybistin I), CB2 (collybistin II), and CB3 (hPEM2-like) and also denoted $\mathrm{SH} 3$ domain usage (e.g., $\mathrm{CB}_{2 \mathrm{SH}}+$ or $\mathrm{CB} 2_{\mathrm{SH} 3}$ ). In postnatal rodent spinal cord and brain, our RT-PCR assays predict that the $\mathrm{CB} 2 \mathrm{SH}_{3}$ and $\mathrm{CB}_{\mathrm{SH}_{3}+}$ isoforms are predominant (Fig. $1 B, C)$. CB1 isoforms were not detected in any of our rodent mRNAs but might be expressed in different tissues or at other developmental stages. To confirm these results, we cloned and sequenced full-length $\mathrm{cDNAs}$ for rat collybistin from rat wholebrain mRNA. Only $\mathrm{CB} 2 \mathrm{SH}_{3}$ and $\mathrm{CB} 3_{\mathrm{SH} 3}+\mathrm{cDNAs}$ were found in a ratio of 5:4 (nine independent isolates). In human brain and spinal cord, only the $\mathrm{CB} 3_{\mathrm{SH} 3}+$ isoform was present; transcripts encoding $\mathrm{CB} 1$ and $\mathrm{CB} 2$ variants were not detected (Fig. 1C). Last, BLAST analysis revealed that rat collybistins and hPEM-2 are most closely related to ARHGEF4 (ASEF/KIAA1112) (Kawasaki et al., 2000), Tiam-1 (Habets et al., 1994; Worthylake et al., 2000), and $\beta$ PIX/p85Cool-1 (Bagrodia et al., 1998; Manser et al., 1998), all of which specifically activate the GTPase Rac1 but not Cdc42.

\section{Functional domains of collybistin required for gephyrin submembrane targeting}

Full-length cDNAs for $\mathrm{CB} 2_{\mathrm{SH} 3+}$ and $\mathrm{CB}_{\mathrm{SH}_{3}+}$ (supplemental Fig. 1, available at www.jneurosci.org) were tagged with the 9E10 epitope at the $\mathrm{N}$ terminus of the expressed protein. To test the activity of these recombinant collybistin isoforms, we also created a plasmid construct (pEGFP-gephyrin) in which EGFP is fused to the $\mathrm{N}$ terminus of gephyrin (P1 isoform) (Prior et al., 1992). This allows discrimination of living cells possessing extensive submembrane microaggregates from those showing intracellular gephyrin deposits (Kins et al., 2000) using fluorescence microscopy. When transfected into HEK293 cells, myc-CB2 $2_{\mathrm{SH} 3}$ is diffusely distributed throughout the cytoplasm (Fig. 1E). Although they were not serum-starved, some cells showing high levels of myc staining exhibited filopodia (MacKay and Hall, 1998), 

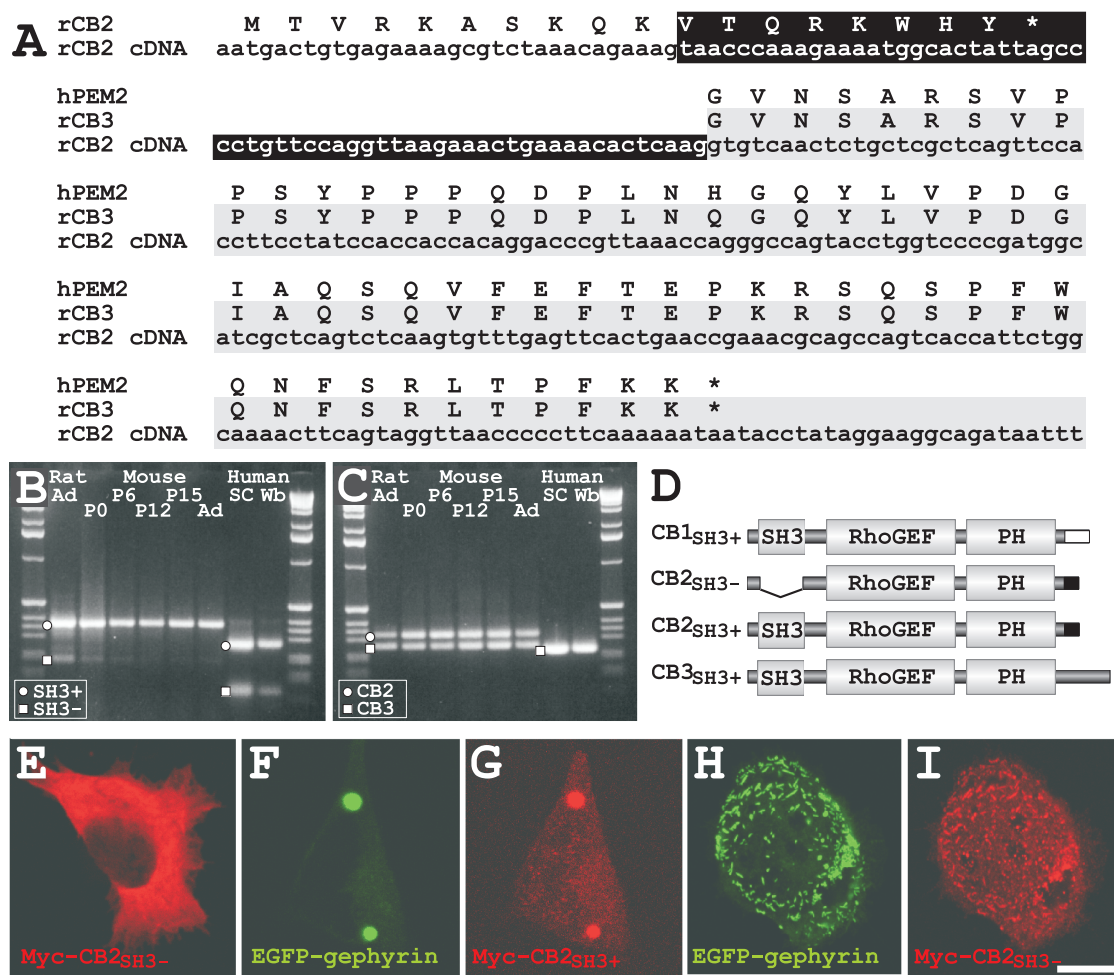

Figure 1. Alternative splicing of rat and human collybistin mRNAs. Three different collybistin C termini can be specified in the rat by the use of different cassette exons. For example, the (B2 (VTQRKWHY*) ( terminus is generated by insertion of a 62 bp exon $(A$, white lettering on black background). When omitted, an alternative $C$ terminus is specified (CB3) that is virtually identical to the $C$ terminus of human collybistin (hPEM-2). RT-PCR analysis shows that the exon encoding the N-terminal SH3 domain $(B)$ is used in most rodent and human collybistin mRNAs $\left(\mathrm{O}_{\mathrm{SH}_{3}+} ; \square, \mathrm{sH}_{3}\right)$. For C-terminal exons $(\mathrm{O})$, both $\mathrm{CB} 2(\mathrm{O})$ and $\mathrm{CB} 3(\square)$ are common in rodents, but only $C B 3$ transcripts are evident in humans. D, Schematic diagram of the primary structures of known collybistin isoforms. Sequences encoding the SH3, RhoGEF, and PH domains in the collybistin isoforms are indicated by gray boxes, and the different $\mathrm{C}$ termini are indicated by white (CB1), black (CB2), or gray (CB3) boxes. E, Expression of myc-tagged $\mathrm{CB}_{\mathrm{SH}_{3} \text { - in }}$ HEK293 cells. F, G, Cotransfection of a plasmid construct encoding EGFP-gephyrin results in the formation of cytoplasmic aggregates $(F)$ to which myc- $\mathrm{CB}_{\mathrm{SH} 3}+$ targets $(G)$. However, coexpression of EGFP-gephyrin with the CB2 variant lacking the $\mathrm{SH} 3$ domain (myc- $\mathrm{CB}_{\mathrm{SH}_{3}-}$ ) results in a redistribution of EGFP-gephyrin and collybistin to submembrane microaggregates $(H, I)$. $S$ cale bar, $10 \mu \mathrm{m}$. Note that $E-G$ are single Z-plane confocal images, whereas $H$ and $/$ are Z-stacks at the cell surface.
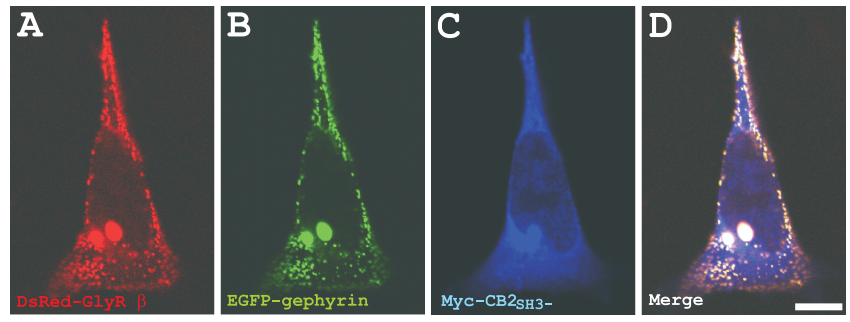

Figure 2. A DsRed-GlyR $\beta$ fusion protein is efficiently targeted to EGFP-gephyrin aggregates in HEK293 cells. Z-stack confocal images showing triple transfection of HEK293 cells with plasmid constructs encoding a DsRed-GlyR $\beta$ subunit intracellular loop fusion protein ( $A$; DsRedGlyR $\beta$ ), EGFP-gephyrin $(B)$, and myC-CB2 SH3 $_{-}$( () . Note that DsRed-GlyR $\beta$ is readily trapped by EGFP-gephyrin submembrane clusters, whereas myc- $\mathrm{CB}_{\mathrm{SH} 3}$ - has a more diffuse distribution pattern throughout the cytoplasm (D). Scale bar, $10 \mu \mathrm{m}$.

whereas others also displayed membrane ruffling (Fig. $1 E$ ). In contrast, EGFP-gephyrin expression resulted in the formation of large intracellular deposits (Fig. $1 F$ ), which are consistent with those observed using nontagged gephyrin (Kirsch et al., 1995). Coexpression of CB2 isoforms with EGFP-gephyrin revealed that the common $\mathrm{SH} 3$-containing variant $\left(\mathrm{myc}^{-\mathrm{CB}} \mathrm{SH}_{3+}\right)$ behaved exactly like collybistin I (Kins et al., 2000) and redistributed to large intracytoplasmic EGFP-gephyrin aggregates (Fig. 1G). In

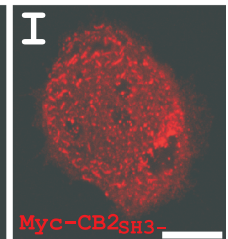

contrast, the variant lacking the $\mathrm{SH} 3$ domain (myc-CB2 ${ }_{\mathrm{SH} 3-}$ ), redistributed with EGFP-gephyrin to submembrane microaggregates in $\sim 40 \%$ of cotransfected cells (Fig. $1 \mathrm{H}, I$ ), whereas others demonstrated different phenotypes (e.g., intracellular aggregates with extended filamentous structures; data not shown). Transfection of HEK293 cells with myc-CB2 $2_{\mathrm{SH}_{3}-}$, EGFP-gephyrin and red fluorescent protein-conjugated GlyR $\beta$ subunit intracellular loop (DsRed-GlyR $\beta$ ) resulted in collybistin-mediated translocation of EGFP-gephyrin to submembrane clusters that were also decorated by DsRed-GlyR $\beta$ (Fig. $2 A-D$ ). However, it is noteworthy that the expression of myc-CB2 $2_{\mathrm{SH} 3}-$ was not restricted to EGFP-gephyrin/DsRedGlyR $\beta$ clusters (Fig. $2 C, D$ ).

\section{Functional analyses of collybistin isoforms and mutants in transfected neurons}

To assess the possible contribution of collybistin to endogenous gephyrin clustering, we transfected selected collybistin constructs into cultured cortical neurons. Although collybistin has been speculated to represent a synaptic protein (Kins et al., 2000; Kneussel and Betz, 2000), we found myc-CB2 ${ }_{\mathrm{SH} 3}$ and myc-CB2 $2_{\mathrm{SH} 3}$ - to be diffusely distributed throughout the soma and dendrites of transfected cortical neurons (Fig. 3A-D). Recombinant myc$\mathrm{CB} 2 \mathrm{SH}_{3}+$ and myc-CB2 $\mathrm{SH}_{3}-$ did not significantly affect endogenous gephyrin clustering (Fig. $3 E$ ). For myc-CB2 ${ }_{\mathrm{SH} 3+}$ the average number of gephyrin clusters was $9.96 \pm 2.13$ per $40 \mu \mathrm{m}$ segment per cell versus $9.86 \pm 2.27$ for myc-CB2 $2_{\mathrm{SH} 3-}(n=11$ neurons per construct). The average cluster size was $1.60 \pm 0.84 \mu \mathrm{m}$ for myc$\mathrm{CB} 2{ }_{\mathrm{SH} 3}+$ versus $1.39 \pm 0.47$ for myc-CB2 $2_{\mathrm{SH} 3-}(n=11$ neurons per construct). We next attempted to construct dominantnegative mutants of CB2 (Fig. 3, inset) to test the proposed function of collybistin in gephyrin clustering in neurons. Deletions of the RhoGEF domain (amino acids 114-293) or the PH domain (amino acids 326-432) were made in the $\mathrm{CB}_{\mathrm{SH}_{3}-}$ isoform. On expression in HEK293 cells, deletion of the RhoGEF domain (myc-CB2 ${ }_{\mathrm{SH} 3}-\Delta$ RhoGEF) abolished gephyrin-collybistin colocalization and EGFP-gephyrin submembrane targeting (Fig. $3 F, G)$. In contrast, deletion of the $\mathrm{PH}$ domain in myc-CB2 $\mathrm{SH}_{3}-$ (i.e., myc-CB2 ${ }_{\mathrm{SH} 3}-\Delta \mathrm{PH}$ ) resulted in the production of cytoplasmic collybistin-gephyrin aggregates (Fig. $3 H, I$ ), indicating that the $\mathrm{PH}$ domain was required for normal targeting of this protein. As expected, myc-CB2 ${ }_{\mathrm{SH}_{3}-} \Delta \mathrm{PH}$ also interfered effectively with clustering of gephyrin in neurons: dendritic clusters of endogenous gephyrin (as visualized by immunostaining with mAb7a) were almost completely eliminated after expression of this deletion mutant (Fig. $3 \mathrm{~J}, \mathrm{~K}$ ). The average number of gephyrin clusters for myc-CB2 ${ }_{\mathrm{SH}_{3}-} \Delta \mathrm{PH}$ was significantly reduced to $2.1 \pm 1.13$ clusters per $40 \mu \mathrm{m}$ segment per cell ( $n=10$ neurons) (Fig. $3 E$ ), when compared with either myc-CB2 $2_{\mathrm{SH}_{3}+}$ or myc-CB2 $\mathrm{SH}_{3-}$ $\left(p<0.001\right.$; Student's $t$ test). Thus, myc-CB2 ${ }_{\mathrm{SH}_{3}-} \Delta \mathrm{PH}$ effec- 
tively competes with endogenous collybistin for binding to gephyrin, causing mislocalization of endogenous gephyrin (Fig. $3 \mathrm{~J}, \mathrm{~K}$, arrows). Note that dendrites of nontransfected control cells demonstrated robust gephyrin clustering (Fig. 3J).

\section{Mapping of binding sites for collybistin and the GlyR $\beta$ subunit on gephyrin} Although the binding sites for gephyrin on collybistin and the GlyR $\beta$ subunit have been described previously (Kneussel et al., 1999a; Grosskreutz et al., 2001), the corresponding binding sites on gephyrin have remained elusive. Several studies have suggested that the binding site for the GlyR $\beta$ subunit lies within the N-terminal MogA domain (Meier et al., 2000; Schwarz et al., 2001; Xiang et al., 2001) or the "linker region" of gephyrin (Prior et al., 1992). However, these studies are complicated by the fact that the MogA domain forms trimers (Sola et al., 2001; Schwarz et al., 2001), whereas the C-terminal MoeA domain probably dimerizes in a manner similar to the E. coli MoeA protein (Schrag et al., 2001; Xiang et al., 2001). To define the regions involved in collybistin-gephyrin and GlyR $\beta$-gephyrin interactions, we used the GAL4 yeast two-hybrid system (Fields and Song, 1989). Full-length rat gephyrin (P1 isoform) (Prior et al., 1992) interacted readily with baits for $\mathrm{CB}_{2}{ }_{\mathrm{SH}}-$ and the large intracellular loop of the human GlyR $\beta$ subunit (Rees et al., 2003) (Fig. 4A). N-terminal truncations of gephyrin lacking the MogA domain and the linker region revealed normal interaction with the GlyR $\beta$-subunit bait (deletions 92, 184, 276, 305, and 323) (Fig. $4 A)$. The same gephyrin constructs, except deletion 323, also showed normal interaction with the $\mathrm{CB} 2 \mathrm{SH}_{3}$ - bait (Fig. $4 A, B$ ). This finding is significant, because the GlyR $\beta$ bait shows a strong interaction with deletion 323 , indicating that this gephyrin fragment is indeed expressed in yeast (Fig. 4A,B). Deletions at either end of the MoeA homology domain of gephyrin (deletions 336, 643, 674, or 704) abolished both $\mathrm{CB} 2{ }_{\mathrm{SH} 3}-$ and GlyR $\beta$ subunit interactions. A bait corresponding to the MoeA homology domain of gephyrin revealed that although deletions 305 and 323 showed strong MoeA-MoeA interactions (Fig. 4B), deletions 336, 643, 674, and 704 either impaired or abolished MoeA-MoeA multimerization.

Because deletions 305 and 323 appeared to demarcate a region important for collybistin-gephyrin interactions, we used an alanine mutation scan across this region to further define the amino acids involved. This revealed that mutants A4 and A5, which together span the short peptide sequence PFPLTSMDKA (Fig. $4 C, D)$, disrupted collybistin-gephyrin interactions without affecting the GlyR $\beta$-gephyrin interaction. It is noteworthy that the P-F-P motif at the beginning of the putative collybistin-binding motif is lost in the deletion construct 323 (Fig. 4D). Mutation of residues flanking the PFPLTSMDKA motif (mutants Geph-A3 and GephA6) did not affect collybistin-gephyrin or GlyR $\beta$-gephyrin interac- tions in yeast (Fig. 4C,D). To test whether the A4 and A5 alanine mutants disrupted collybistin-gephyrin colocalization in mammalian cells, we next introduced these mutations into pEGFP-gephyrin. These mutations were sufficient to either disrupt (EGFP-GephA4) or severely weaken (EGFP-GephA5) collybistin-gephyrin colocalization (Fig. $4 E$ ) after coexpression with myc-CB2 ${ }_{\mathrm{SH} 3}$ in HEK293 cells. In addition, submembrane targeting was abolished for both EGFP-A4 and EGFP-A5 (Fig. 4E).

Expression of EGFP-gephyrin in transfected cortical neurons resulted in punctate staining throughout dendritic processes (Fig. 5A), which colocalizes with staining for mAb7a (gephyrin) and GAD (Fig. 5E). However, when neurons were transfected with the EGFP-GephA4 mutant, dendritic puncta were dramatically reduced. Two main phenotypes were noted: either gephyrin accumulated in large aggregates in the cell soma (Fig. 5B) or cell soma plus dendrites (Fig. 5C). These gephyrin aggregates were no longer juxtaposed to GABAergic terminals (Fig. $5 F, G$ ). Therefore, EGFP-GephA4 acts as a dominant-negative factor trapping endogenous gephyrin and preventing proper apposition of pre- 


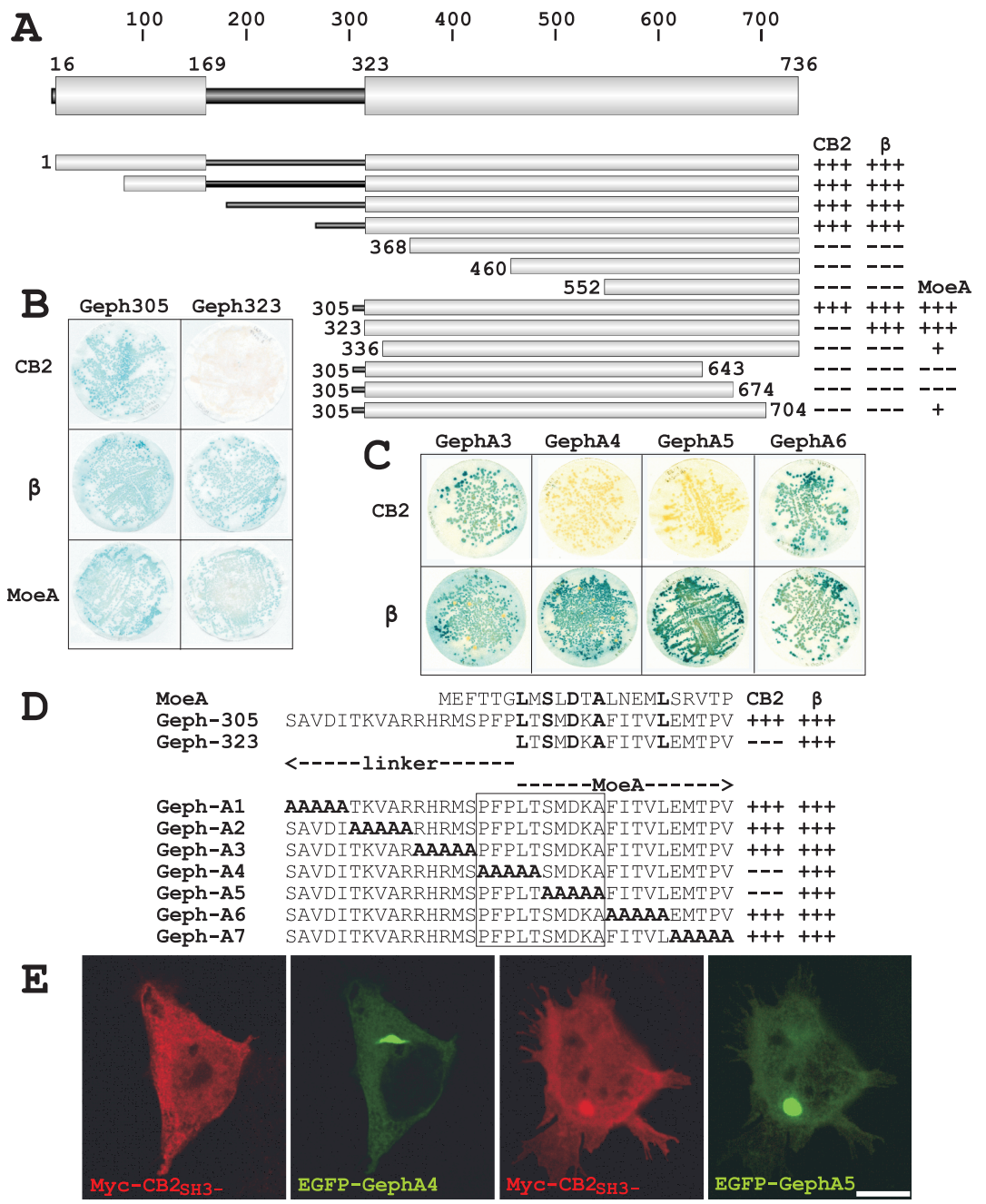

Figure 4. Mapping of the collybistin binding site on gephyrin. $A$, Deletion constructs of the rat gephyrin $\mathrm{P} 1$ isoform in pACT2 (Clontech) were tested using the GlyR $\beta$ subunit intracellular loop $(\beta)$ and full-length collybistin $\mathrm{CB}_{\mathrm{SH}_{3}-}$ isoform (CB2) as baits. Both proteins interact with full-length gephyrin in yeast, as judged by a semiquantitative LacZ assay $(+++$, strong interaction + , weak interaction; - , no interaction). Deletion analysis indicated that the gephyrin MogA domain (MogA) and most of the linker region do not appear to contribute to either GlyR $\beta$ subunit or collybistin binding. Deletions into the gephyrin MoeA domain (MoeA) destroy interactions with both collybistin and the GlyR $\beta$ subunit because of the loss of MoeA-MoeA domain interactions. $B$, Geph-305 interacts with GlyR $\beta, \mathrm{CB}_{\mathrm{SH} 3-}$, and MoeA domain baits, whereas Geph-323 (which corresponds to a MoeA domain prey) interacts with GlyR $\beta$ and MoeA but not $\mathrm{CB}_{\mathrm{SH}_{3}-}$. C, D, Mutants (Geph-A1 to Geph-A7), which span the Geph-305 to Geph 323 region, were then constructed and tested in yeast assays. Mutations Geph-A4 and Geph-A5 (boxed) abolished interactions with $\mathrm{CB}_{\mathrm{SH} 3}$ - but not the GlyR $\beta$ subunit $(C, D)$. The corresponding mutants in EGFP-gephyrin eliminated (EGFP-GephA4) or weakened (EGFP-GephA5) colocalization with myc- $\mathrm{CB}_{\mathrm{SH}_{3}-}(E)$ and blocked submembrane microaggregate formation. Scale bar, $10 \mu \mathrm{m}$.

synaptic and postsynaptic structures. In contrast, mutant EGFPGephA5 shows a few large dendritic clusters and appears to trap endogenous gephyrin at these sites (Fig. 5D,H). Quantitative analysis (Fig. 5I) demonstrated that the average endogenous gephyrin cluster number (mAb7a immunofluorescence) was reduced to $2 \pm 1.95$ clusters per $40 \mu \mathrm{m}$ segment per cell for EGFPGephA4 ( $n=12$ neurons) and $4.63 \pm 2.01$ clusters for EGFPGephA5 per $40 \mu \mathrm{m}$ segment per cell. These results were statistically significant when compared with EGFP-gephyrin, which showed an average of $9.77 \pm 2.74$ clusters per $40 \mu \mathrm{m}$ segment per cell ( $n=13$ neurons; $p<0.001$; Student's $t$ test). In summary, both EGFP-GephA4 and EGFP-GephA5 mutants effectively interfere with clustering of endogenous gephyrin in transfected cortical neurons. As in HEK293 cells (Fig. 4E), mutant EGFP-GephA4 is particularly effective, leading to a fivefold reduction of endogenous gephyrin clusters.

\section{ARHGEF9 as a candidate gene for hyperekplexia}

Hereditary hyperekplexia is a neurological disorder characterized by an excessive startle response, which can be caused by diverse dominant and recessive mutations in the genes encoding the GlyR $\alpha 1$ (GLRA1) (Rees et al., 2001) or $\beta$ subunits (GLRB) (Rees et al., 2002). However, a significant portion of patients with hyperekplexia does not appear to have mutations in either GLRA1 (Vergouwe et al., 1997) or GLRB (Rees et al., 2002), suggesting that other components of the GlyR signaling complex, such as gephyrin (GPHN) (Rees et al., 2003) and collybistin (gene symbol: ARHGEF9) may be involved. ARHGEF9 consists of 10 exons distributed over $\sim 190$ $\mathrm{kb}$ of human chromosome Xq22.1 (Fig. $6 A$; supplemental Table 1 , available at www.jneurosci.org). EST analysis revealed the existence of two alternative first exons (denoted exons 1a and 1b) (supplemental Table 1, available at www.jneurosci.org), suggesting that ARHGEF9 has two promoters that might control tissue-specific or developmentally regulated changes in gene expression. Exon 1a encodes a long $\mathrm{N}$ terminus (MQWIRGGSGM), whereas exon $1 \mathrm{~b}$ encodes a shorter sequence (MTL). Exons 1a and 1b do not appear to influence utilization of exon 2, which encodes the SH3 domain (data not shown).

We used PCR (primers listed in supplemental Table 2, available at www. jneurosci.org) and automated dHPLC to detect ARHGEF9 mutations and polymorphisms in a cohort of 32 hyperekplexia patients. Two SNPs were detected in the intronic regions of exon $1 \mathrm{~b}$ (IVS2 $+43 \mathrm{tc}$; het $=0.05)$ and exon 10 (IVS11 $-64 \mathrm{tc}$; het $=0.04)$ in both male and female patients and control cohorts. Significantly, a missense mutation (G164C) in the $A R H$ GEF9 coding region was discovered in one patient, which causes a glycine to alanine (G55A) substitution at position 55 of hPEM-2 (Fig. 6B, $C$, inset). The mutant genotype creates a NlaIII restriction site $\left(5^{\prime}-G A T G-3^{\prime}\right.$ to $\left.5^{\prime}-C A T G-3^{\prime}\right)$, a situation which was not detected in over 200 unrelated Caucasian control chromosomes (Fig. 6D). A glycine residue is found at the equivalent position in 97\% of known SH3 domains (2580/2669) as assessed by using psiBLAST (www.biology.wustl.edu/gcg/psiblast.html) against the National Center for Biotechnology Information nonredundant database. A molecular model of the $\mathrm{SH} 3$ domain structure (Fig. 6E) shows that the G55A substitution lies in the middle of a $\beta$ strand, and that this position of the protein backbone has Phi/Psi angles just beyond the limits of what is normally allowed for a nonglycine amino acid. G55A lies proximal to one of a series of residues that has been implicated in binding the proline-rich motif (Fig. 6B).

The patient was the first-born child of a 32-year-old woman, delivered in the thirty-sixth week of gestation. Immediately after 
delivery, cyanosis and muscular stiffness (suggestive of muscular hypertonia) were noted. The child also appeared to stare. During the following weeks, the child developed tonic seizures that were provoked by tactile stimulation. To counter the seizures, initially phenobarbital and then lamotrigene were administered. Although the latter treatment was initially effective, after three and one-half months of age, the seizures recurred and were often precipitated by extreme emotions. At 4 months of age, a diagnosis of hyperekplexia was made, but therapy with clonazepam was unsuccessful. EEG monitoring coupled with ambulatory video revealed that the seizures were both hyperekplectic and epileptic in origin. During the following years, the child suffered from frequent long-lasting seizures, accompanied by the arrest and later decline of psychomotor development. Eventually, a progressive epileptic encephalopathy as well as hyperekplexia became evident and poly-drug treatment failed to provide adequate longterm seizure control. At four years of age, the subject was severely retarded and suffered almost daily severe long-lasting fits both epileptic and nonepileptic in origin, eventually leading to death at the age of 4 years and 4 months.

\section{Functional analysis of the G55A mutation}

The clinical symptoms above are consistent with a mislocalization of neuronal gephyrin and associated glycine and $\mathrm{GABA}_{\mathrm{A}}$ receptors. We therefore assessed possible functional consequences of the G55A mutation. Unlike myc-CB2 $2_{\mathrm{SH} 3}$ (Fig. $1 G$ ) or myc$\mathrm{CB}_{\mathrm{SH}_{3}+}$ (Fig. $6 \mathrm{~F}$ ), myc-CB3 ${ }_{\mathrm{SH} 3+}$ G55A did not colocalize with large cytoplasmic EGFP-gephyrin aggregates in transfected HEK293 cells, but like myc-CB2 $2_{\mathrm{SH} 3-}$ (Fig. $1 \mathrm{I}$ ), myc-CB3 ${ }_{\mathrm{SH} 3+} \mathrm{G} 55 \mathrm{~A}$ translocated gephyrin to submembrane microaggregates (Fig. 6G). This result suggests that the G55A mutation disrupts the $\mathrm{SH} 3$ domain structure and function. In cortical neurons, wild-type myc-CB3 $3_{\mathrm{SH} 3+}$ is diffusely expressed within the soma and proximal and distal dendrites and does not influence endogenous gephyrin clustering (Fig. $6 \mathrm{H}-$ $J, Q$ ). The average gephyrin cluster number was $11.9 \pm 4.44$ per 40 $\mu \mathrm{m}$ dendritic segment ( $n=11$ neurons) for myc-CB3 $3_{\mathrm{SH} 3+}$. In contrast, myc-CB3 $3_{\mathrm{SH} 3+} \mathrm{G} 55 \mathrm{~A}$ forms a tight association with endogenous gephyrin and is confined to the cell soma and proximal dendrites, indicating a deficit in dendritic trafficking of this mutant protein (Fig. $6 K-M)$. In another subset of cells, myc$\mathrm{CB}_{\mathrm{SH}_{3}+} \mathrm{G} 55 \mathrm{~A}$ is found in large somatic and dendritic aggregates (Fig. 6N-P), which results in an almost complete loss of gephyrin clusters. Quantitative analysis of gephyrin clustering shows that expression of myc-CB3 ${ }_{\mathrm{SH} 3+} \mathrm{G} 55 \mathrm{~A}$ results in a dramatic loss of endogenous gephyrin clusters (Fig. 6Q). The average cluster number (mAb7a immunofluorescence) was reduced to $1.55 \pm$ 0.72 clusters per $40 \mu \mathrm{m}$ segment per cell for myc-CB3 ${ }_{\mathrm{SH} 3+} \mathrm{G} 55 \mathrm{~A}$, which is statistically significant compared with myc-CB3 $3_{\mathrm{SH} 3+}$ ( $n=11$ cells per construct; $p<0.001$; Student's $t$ test).

To address possible functional consequences at inhibitory synapses, we assessed whether transfection of myc-CB3 ${ }_{\mathrm{SH} 3+} \mathrm{G} 55 \mathrm{~A}$ would affect postsynaptic localization of $\mathrm{GABA}_{\mathrm{A}}$ receptors. Triple staining of neurons transfected with myc- $\mathrm{CB} 3_{\mathrm{SH} 3}+$ with antibodies specific
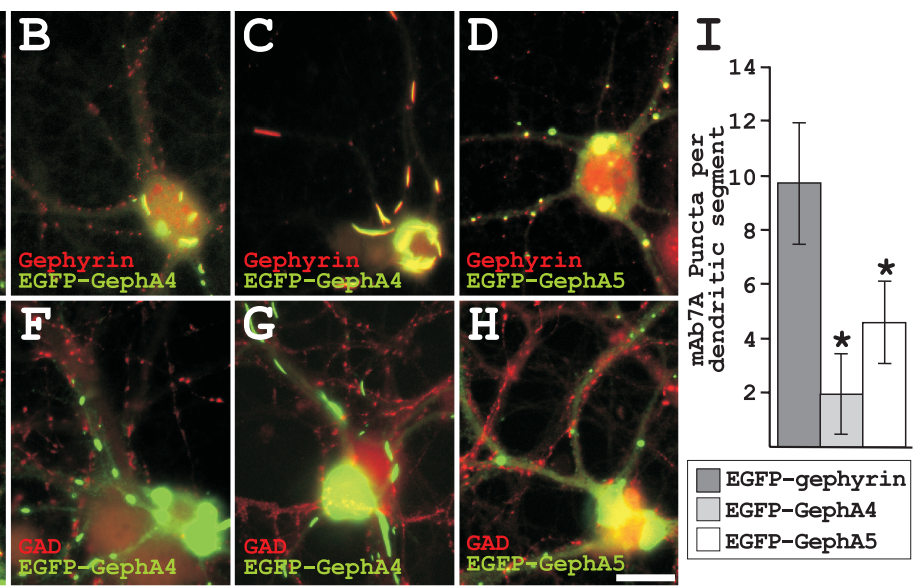

EGLP-Geph

Fure 5. Disruption of the collybistin binding site on gephyrin prevents accumulation of gephyrin at postsynaptic sites. $A-H$, gephyrin $(A, E)$ and the mutants EGFP-GephA4 $(B, C, F, G)$ and EGFP-GephA5 $(D, H)$ were transfected into cortical folocalized with EGFP-gephyrin. EGFP-gephyrin is localized at postsynaptic sites juxtaposed to presynaptic GAD $(E$, 作 ephyrin clusters ( $\left(;{ }^{*} p<0.001\right.$; Student's $t$ test; $n=12-13$ cells per construct) for the EGFP-GephA4 and EGFP-GephA5 mutants

for this construct, for GABA terminals $(G A D)$ and for the $G_{A B A}$ receptor $\gamma 2$ subunit revealed, as expected, diffuse distribution of this collybistin isoform and proper localization of $\mathrm{GABA}_{\mathrm{A}}$ receptors at postsynaptic sites (Fig. $7 A-D$ ). Enlargement of a dendritic segment (Fig. $7 E-H$ ) shows clear colocalization of $\mathrm{GABA}_{\mathrm{A}}$ receptors (red) and GAD (blue) resulting in purple puncta (Fig. $7 \mathrm{H}$, arrows). In contrast, in neurons transfected with myc$\mathrm{CB} 3{ }_{\mathrm{SH} 3+} \mathrm{G} 55 \mathrm{~A}, \mathrm{GABA}_{\mathrm{A}}$ receptors were essentially absent from the dendritic compartment (Fig. 7I-P). Quantitative analysis of $\mathrm{GABA}_{\mathrm{A}}$ receptor clustering (Fig. 7Q) shows that the average cluster number was reduced to $2.08 \pm 1.29$ clusters per $40 \mu \mathrm{m}$ segment per cell for myc-CB3 ${ }_{\mathrm{SH} 3+} \mathrm{G} 55 \mathrm{~A}$, which is statistically significant when compared with $10.04 \pm 1.57$ clusters for myc$\mathrm{CB}_{\mathrm{SH} 3+}(n=12$ cells per construct; $p<0.001$; Student's $t$ test $)$. This mislocalization of $\mathrm{GABA}_{\mathrm{A}}$ receptors, together with a corresponding expected deficit in glycine receptor trafficking in brain stem and spinal cord neurons, is likely to be causal for the clinical phenotype of the patient described above.

\section{Discussion}

The dendritic trafficking of receptors and clustering at appropriate sites in the postsynaptic membrane are extremely important events in the formation of functional synapses. This study reveals that the RhoGEF collybistin is a key molecule in regulating synaptic localization of gephyrin and by association, $\mathrm{GABA}_{\mathrm{A}}$ and glycine receptors. First, we reported the characterization of new variants of collybistin, which are created by alternative splicing of exons encoding an $\mathrm{N}$-terminal src homology 3 domain and three alternate $\mathrm{C}$ termini (CB1, CB2, and CB3). Secondly, we have shown that the $\mathrm{SH} 3$ domain negatively regulates the ability of collybistin to translocate gephyrin to submembrane microaggregates in HEK293 cells. Because most endogenous collybistin isoforms harbor this region, this strongly suggests that collybistin activity is regulated by protein-protein interactions at the $\mathrm{SH} 3$ 


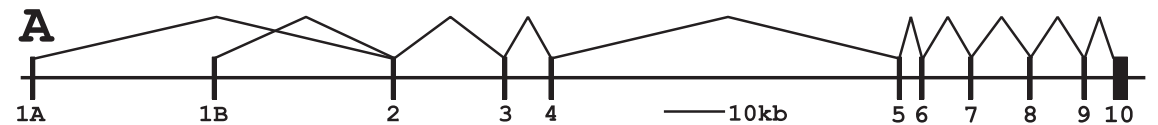

B hPEM2: MTLLITGDSIVSAEAVWDHVTMANRELAFKAGDVIKVLDASNKDWWWGQIDDEEGWFPASFVRLWVNQE $B_{\text {G55A: }}$ MTLLITGDSIVSAE.AVWDHVTMANRELAFKAGDVIKVLDASNKDWWWGQIDDEEAWFPASFVRLWVNQE

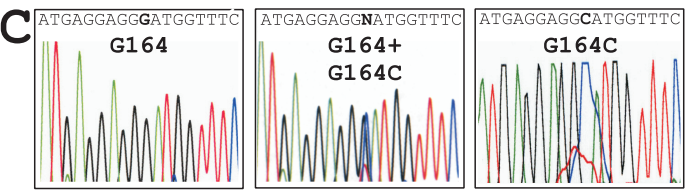
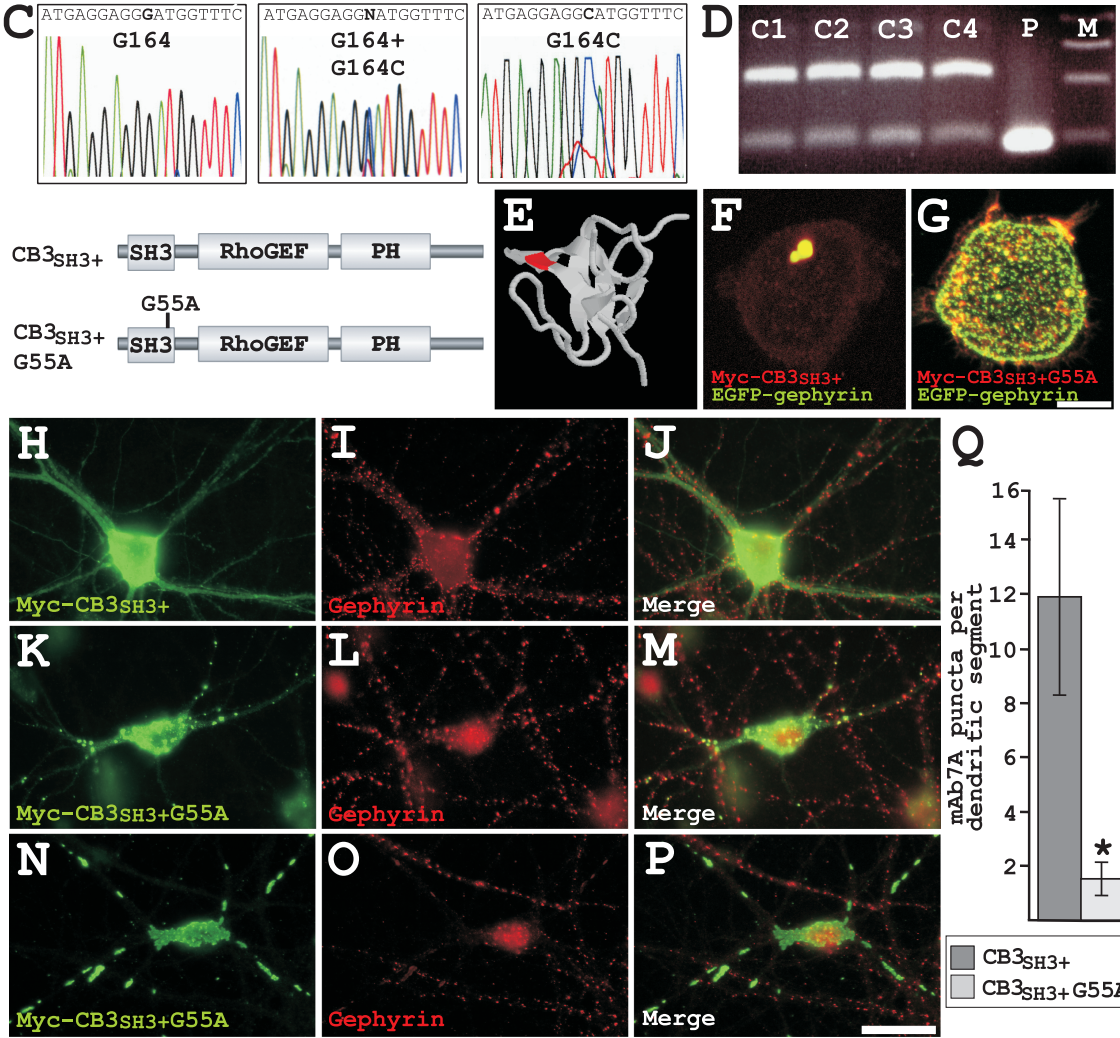

Figure 6. Mutation of G55A in a patient with hyperekplexia and epilepsy. $A$, Genomic structure of the human collybistin gene (ARHGEF9) encoding hPEM-2. B, The location of the mutation G55A (red lettering) in the N-terminal SH3 domain (underlined) of $\mathrm{hPEM}-2$ is shown. G55A lies proximal to one of the series of residues that have been proposed to bind proline-rich motifs (blue lettering). C, DNA sequencing of exon 2 samples revealed a $G$ to $C$ substitution at position 164 of the collybistin coding sequence, causing a G55A missense mutation in the N-terminal SH3 domain of hPEM2. G164, Control sample; G164 + G164C, ad-mixture of the patient sample with a female DNA control; G164C, G164C mutation. D, Restriction fragment length polymorphism analysis of the G55A mutation: the G164C mutation creates a novel Nlall site at position 207 of the 313 bp exon 2 PCR fragment. This, in conjunction with another NIallI site at position 106, generates convergent fragments of 106, 101, and 106 bp in the patient DNA sample (denoted P). Normal controls (C1-C4) have fragments of 207 and $106 \mathrm{bp}$. E, A molecular model showing the location of G55 in the SH3 domain structure calculated with Swiss-Model (Guex and Peitsch, 1997). F, G, Confocal images showing HEK293 cells transfected with plasmid constructs for myc-CB3 ${ }_{\mathrm{SH}_{3}+}$ and EGFP-gephyrin ( $F$ ) or myc-CB3 ${ }_{\mathrm{SH}_{3}+} \mathrm{G55A}$ and EGFP-gephyrin ( $G$ ). Note that myc- $\mathrm{CB}_{\mathrm{SH}_{3}+}$ colocalizes with cytoplasmic EGFP-gephyrin aggregates, whereas myc- $\mathrm{CB}_{\mathrm{SH} 3}+\mathrm{G} 55 \mathrm{~A}$ results in submembrane microclusters of EGFP-gephyrin. $H-P$, Confocal images showing myc- $\mathrm{CB}_{\mathrm{SH} 3+}(\mathrm{H}-J)$ and myc-CB3 ${ }_{\mathrm{SH} 3+} \mathrm{G55A}(\mathrm{K}-\mathrm{P})$ expressed in cultured cortical neurons. Although wild-type myc- $\mathrm{CB}_{\mathrm{SH}_{3}+}(H)$ is expressed throughout the cell soma and dendrites and does not disrupt gephyrin localization $(H-J)$, myc- $\mathrm{CB}_{\mathrm{SH}_{3}+} \mathrm{G} 55 \mathrm{~A}$ forms a tight association with endogenous gephyrin in clusters confined to proximal dendrites $(K-M)$. In a subset of transfected cells $(N-P)$, myc-CB3 ${ }_{\mathrm{SH}_{3}+} \mathrm{G} 55 \mathrm{~A}$ forms large somatic and dendritic aggregates, which results in an almost complete loss of gephyrin clusters. Remaining red puncta in $I, L$, and $O$ represent gephyrin clusters from nontransfected cells in the same culture. Quantitative analysis of mAb7a immunofluorescence $(Q)$ indicates a dramatic loss of gephyrin clusters $\left({ }^{*} p<0.001\right.$; Student's $t$ test; $n=11$ cells per construct) for myc- $\mathrm{CB}_{\mathrm{SH} 3+}{ }_{\mathrm{G} 55 \mathrm{~A} \text { mutant }}$ compared with myc-CB3${ }_{\mathrm{SH} 3+}$. Scale bars: $F, G, 10 \mu \mathrm{m} ; \mathrm{H}-P, 35 \mu \mathrm{m}$.

domain. Other functional domains of collybistin are also crucial, because gephyrin clustering requires both collybistin-gephyrin interactions and an intact collybistin $\mathrm{PH}$ domain. Third, we mapped the binding sites for collybistin and the GlyR $\beta$ subunit on gephyrin to the C-terminal MoeA homology domain and show that multimerization of the MoeA domain is a requirement for both collybistin-gephyrin and GlyR-gephyrin interactions. Last, we present the first significant genetic evidence that collybistin is important for the correct synaptic targeting of gephyrin: a G55A mutation in exon 2 of the human collybistin
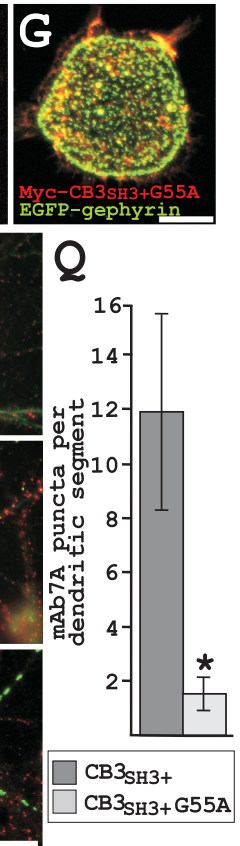

gene (ARHGEF9) results in symptoms of both hyperekplexia and epilepsy, which is likely to be caused by mislocalization of gephyrin and associated GlyR and $\mathrm{GABA}_{\mathrm{A}}$ receptors.

\section{Functional significance of collybistin alternative splicing}

In addition to the original rat collybistin isoforms (now denoted $\mathrm{CB}_{\mathrm{SH}_{3}+}$ and $\left.\mathrm{CB} 2_{\mathrm{SH} 3}\right)$, we cloned two additional isoforms $\left(\mathrm{CB}_{2} \mathrm{SH}_{3}\right.$ and $\left.\mathrm{CB}_{\mathrm{SH}_{3}}\right)$ from neonatal rat brain. We also determined that the $\mathrm{CB} 2$ and $\mathrm{CB} 3$ isoforms are of equal abundance in postnatal rat or mouse brain (CB1 was not detected), and that in adult human spinal cord and brain, $\mathrm{CB}_{\mathrm{SH} 3+}$ (but not CB1 or CB2) was detected. Alternative splicing of $\mathrm{N}$ - and $\mathrm{C}$-terminal exons indicates that care must be applied in interpreting studies using in situ hybridization (Kins et al., 2000; Kneussel et al., 2001a) or when generating collybistin-specific antisera. The finding that $\mathrm{CB}_{2 \mathrm{SH} 3+}$ and $\mathrm{CB}_{\mathrm{SH} 3}+$ are functionally inactive in recombinant gephyrin clustering assays is a paradox, because the vast majority of spliced transcripts in rat, mouse, and human spinal cord or brain clearly seem to encode these isoforms. It appears that collybistin activity is regulated via protein-protein interactions or post-translational modifications at the $\mathrm{SH} 3$ domain and that this mechanism only operates correctly in neurons. In this model, collybistin could be "activated" at specific subcellular locations by an SH3-interacting ligand or "trigger protein."

\section{Functional collybistin is required for dendritic clustering of gephyrin}

By overexpressing recombinant collybistin isoforms and mutants in cortical neurons, we demonstrated that collybistin is an essential molecule for dendritic gephyrin clustering and for appropriate trafficking of $\mathrm{GABA}_{\mathrm{A}}$ receptors to synapses. A similar role for collybistin is likely at glycinergic synapses of brainstem and spinal cord neurons. The distribution of epitopetagged collybistin in neurons suggested that the protein is present at, but not limited to, synaptic sites. Analyses of the expression pattern of the $\mathrm{PH}$ domain deletion mutant, $\mathrm{CB} 2_{\mathrm{SH}_{3}-} \Delta \mathrm{PH}$, suggested that collybistin is involved in dendritic transport of gephyrin to inhibitory synapses. Deletion of the $\mathrm{PH}$ domain resulted in accumulation of endogenous gephyrin in proximal dendrites and significantly reduced endogenous gephyrin clustering. Whether this mutation disrupts $\mathrm{PH}$ domain-membrane phosphoinositide interactions, or the binding of one or more key collybistininteracting proteins, remains to be determined. The RhoGEF domain deletion also disrupted submembrane targeting of gephyrin; this is likely because of the fact that $\mathrm{CB}_{2} \mathrm{SH}_{3} \Delta$ Rho- 
GEF no longer interacts with gephyrin, rather than deficits in GDP-GTP exchange.

\section{Interaction of collybistin and GlyR $\beta$ with gephyrin requires \\ MoeA-MoeA interactions}

A C-terminal fragment encompassing amino acids 305-736 of gephyrin displayed robust binding to collybistin and gephyrin, meaning that all of the N-terminal MogA homology domain (amino acids 16-169) and most of the intervening linker region (amino acids 170322) are dispensable for binding these molecules. Furthermore, our results with deletion constructs indicated that the binding site for GlyR $\beta$ must reside entirely within the MoeA homology domain (amino acids 323-736). If the gephyrin MoeA homology domain forms an antiparallel dimer, like E. coli MoeA (Menéndez et al., 1997; Schrag et al., 2001; Xiang et al., 2001), our results strongly suggest that two equivalent GlyR $\beta$ binding sites would be present at the MoeA-MoeA homology domain interface. Whether these two equivalent sites would bind a single GlyR heteromer, which is thought to contain two $\beta$ subunits (stoichiometry $\alpha 1_{3} \beta_{2}$ ) or two distinct receptor pentamers, is presently unclear. Localization of the residues on gephyrin that interact with GlyRs will probably require cocrystallization of the MoeA homology domain with a peptide corresponding to the gephyrin-binding site on the GlyR $\beta$ subunit (Kneussel et al., 1999a). Caution must be exercised with the analysis of mutants that disrupt gephyrin-GlyR $\beta$ subunit interactions, because these may simply be defective in MoeA-MoeA assembly. Ideally, a gephyrin mutant defective in GlyR $\beta$ subunit binding would retain robust MoeA-MoeA interactions and would be translocated to submembrane microaggregates by collybistin.

A putative binding site for collybistin was located to the border of the linker region and MoeA domain. Replacement of two adjacent groups of five amino acids either completely abolished (Geph-A4) or reduced (Geph-A5) collybistin-gephyrin interactions in HEK293 cells but did not affect interaction with the GlyR $\beta$ subunit. When expressed in cortical neurons, EGFP-gephyrin was localized at synaptic sites. This was evidenced by the almost perfect concordance of EGFP-gephyrin fluorescence and mAb7a immunoreactivity, the latter representing both transfected and endogenous gephyrin and by the close apposition of EGFP-gephyrin and presynaptic immunoreactivity for GAD. In contrast, the gephyrin A4 and A5 mutants were both confined to large somatic and dendritic aggregates. These aggregates were not apposed to GAD immunoreactivity, indicating they were mislocalized. Quantitative analyses showed that punctate immunoreactivity for endogenous gephyrin in these transfected cells was severely reduced for EGFPGephA4 and, to a lesser extent, for EGFP-GephA5. Interestingly, in cells expressing high levels of the EGFP-GephA4 mutant, the mutant and endogenous gephyrin proteins were both confined to large structures that extended far into peripheral dendrites. Thus, EGFP-GephA4 is effectively transported to peripheral dendrites, although it cannot by itself interact with colly-
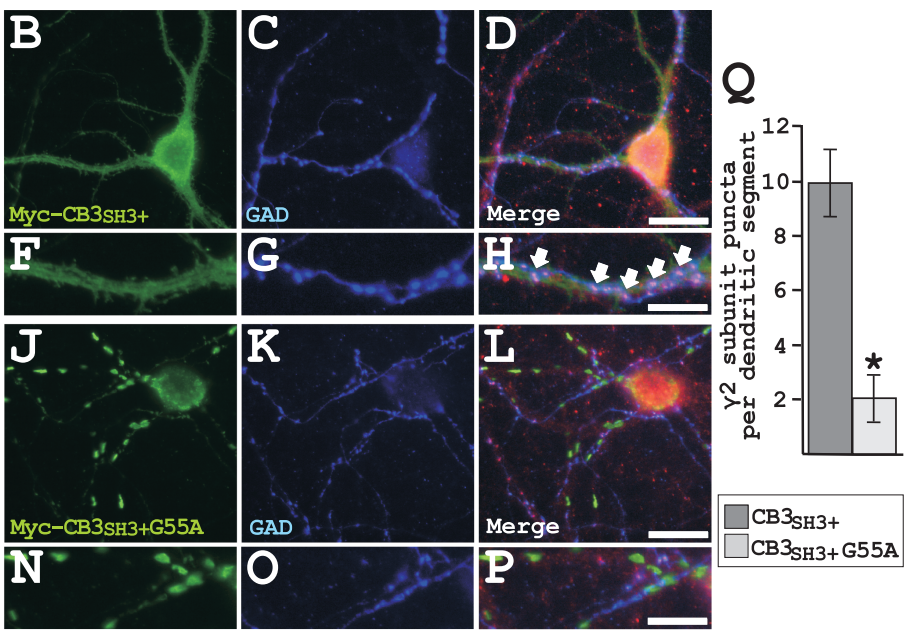

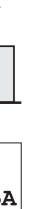

Figure 7. Collybistin mutant $\mathrm{CB}_{\mathrm{SH}_{3}+} \mathrm{G} 55 \mathrm{~A}$ results in loss of $\mathrm{GABA}_{\mathrm{A}}$ receptor clusters. Triple staining of neurons transfected (blue). Note that in myc-CB3 $\mathrm{SH}_{3}$-transfected neurons $(A-D), \mathrm{GABA}_{\mathrm{A}}$ receptor clusters are juxtaposed to in munoreactivity is primarily confined to the cell soma $(I, M)$, and large collybistin aggregates $(J, N)$ are observed throughout the . Note that these collybistin aggregates are not juxtaposed to GABAergic terminals $(K, L, O, P)$. Quantitative analysis of $\gamma 2$ subunit immunofluorescence $(Q)$ indicates a statistically significant loss of $G A B A_{A}$ receptor clusters ( ${ }^{*} p<0.001$; Student's $t$ test; $n=12$ cells per 55 A mutant compared with myc-CB3 ${ }_{\mathrm{SH}_{3}+}$. Scale bars: $A-D, I-L, 25 \mu \mathrm{m} ; E-H, M-P, 12.5 \mu \mathrm{m}$.

bistin. However, some collybistin-dependent trafficking function may be provided indirectly through multimerization of the mutant gephyrin construct with endogenous gephyrin, which remains likely to interact with collybistin. In comparison, EGFP-GephA5 aggregates were smaller and more confined to the soma and proximal dendrites of transfected neurons. Our study identifies a critical sequence in gephyrin (PFPLTSMDKA) that appears to be essential for collybistingephyrin interactions and for normal collybistin-mediated trafficking and clustering of gephyrin to postsynaptic sites.

\section{G55A mutation in the hPEM2 SH3 domain leads to} hyperekplexia and epilepsy

The importance of collybistin for postsynaptic localization of gephyrin and associated ligand-gated chloride channels is underlined by the effect of the G55A mutation in the SH3 domain, leading to symptoms of both hyperekplexia and epilepsy. Recent studies (Douangamath et al., 2002; Groemping et al., 2003; Liu et al., 2003) have shown that there is sometimes binding of ligands to $\mathrm{SH} 3$ domains beyond the proline-rich peptide binding region. However, because the conserved glycine is buried within the $\mathrm{SH} 3$ domain structure, we consider that disrupting SH3 domain folding rather than the binding surface is the most probable mechanism of action. This is supported by studies in transfected HEK293 cells, revealing that the G55A mutation deregulates SH3 domain-containing collybistin isoforms, allowing translocation of gephyrin to submembrane sites in HEK293 cells. However, it is noteworthy that in neurons, myc-CB3 ${ }_{\mathrm{SH}_{3}+} \mathrm{G} 55 \mathrm{~A}$ differs dramatically from other recombinant collybistin isoforms, including myc-CB2 $2_{\mathrm{SH} 3-}$, which lacks the $\mathrm{SH} 3$ domain. $\mathrm{CB}_{\mathrm{SH}_{3}+} \mathrm{G} 55 \mathrm{~A}$ forms a tight association with gephyrin in dendritic clusters or forms large somatic and dendritic aggregates. These findings suggest that the G55A mutation causes a more complex deficit in dendritic trafficking of collybistin and disrupts collybistin-accessory protein interactions. The severe functional consequences of this mutation for the synaptic localization of gephyrin and, by 
association, $\mathrm{GABA}_{\mathrm{A}}$ receptors strongly suggest that the clinical phenotype observed in this patient was a consequence of the loss of gephyrin and major $\mathrm{GABA}_{\mathrm{A}}$ and GlyR subtypes from synaptic sites. Although gene targeting experiments in mice have previously suggested that loss of gephyrin would be lethal in the first postnatal days, gephyrin is not only required for synaptic cluster-

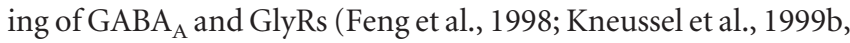
2001b; Levi et al., 2004) but also for molybdoenzyme activity in non-neuronal tissues. Overall, we predict that mutations affecting collybistin function result in a neuronal gephyrin phenotype, whereas peripheral molybdoenzyme-related functions of gephyrin are left undisturbed. The possibility remains that additional mutations in ARHGEF9 may contribute to other cases of X-linked hyperekplexia and epilepsy.

\section{References}

Andrew M, Owen MJ (1997) Hyperekplexia: abnormal startle response due to glycine receptor mutations. Br J Psychiatry 170:106-108.

Bagrodia S, Taylor SJ, Jordon KA, Van Aelst L, Cerione RA (1998) A novel regulator of p21-activated kinases. J Biol Chem 273:23633-23636.

Douangamath A, Filipp FV, Klein AT, Barnett P, Zou P, Voorn-Brouwer T, Vega MC, Mayans OM, Sattler M, Distel B, Wilmanns M (2002) Topography for independent binding of alpha-helical and PPII-helical ligands to a peroxisomal SH3 domain. Mol Cell 10:1007-1017.

Dunne EL, Hosie AM, Wooltorton JR, Duguid IC, Harvey K, Moss SJ, Harvey RJ, Smart TG (2002) An N-terminal histidine regulates $\mathrm{Zn}^{2+}$ inhibition on the murine $\mathrm{GABA}_{\mathrm{A}}$ receptor $\beta 3$ subunit. Br J Pharmacol 137:29-38.

Erickson JW, Cerione RA (2001) Multiple roles for Cdc42 in cell regulation. Curr Opin Cell Biol 13:153-157.

Essrich C, Lorez M, Benson JA, Fritschy JM, Lüscher B (1998) Postsynaptic clustering of major $\mathrm{GABA}_{\mathrm{A}}$ receptor subtypes requires the $\gamma 2$ subunit and gephyrin. Nat Neurosci 1:563-571.

Feng G, Tintrup H, Kirsch J, Nichol MC, Kuhse J, Betz H, Sanes JR (1998) Dual requirement for gephyrin in glycine receptor clustering and molybdoenzyme activity. Science 282:1321-1324.

Fields S, Song O (1989) A novel genetic system to detect protein-protein interactions. Nature 340:245-246.

Fritschy JM, Mohler H (1995) $\mathrm{GABA}_{\mathrm{A}}$-receptor heterogeneity in the adult rat brain: differential regional and cellular distribution of seven major subunits. J Comp Neurol 359:154-194.

Fuhrmann JC, Kins S, Rostaing P, El Far O, Kirsch J, Sheng M, Triller A, Betz H, Kneussel M (2002) Gephyrin interacts with dynein light chains 1 and 2, components of motor protein complexes. J Neurosci 22:5393-5402.

Fuller KJ, Morse MA, White JH, Dowell SJ, Sims MJ (1998) Development of a yeast trihybrid screen using stable yeast strains and regulated protein expression. Biotechniques 25:85-92.

Giesemann T, Schwarz G, Nawrotzki R, Berhorster K, Rothkegel M, Schluter K, Schrader N, Schindelin H, Mendel RR, Kirsch J, Jockusch BM (2003) Complex formation between the postsynaptic scaffolding protein gephyrin, profilin, and Mena: a possible link to the microfilament system. J Neurosci 23:8330-8339.

Groemping Y, Lapouge K, Smerdon SJ, Rittinger K (2003) Molecular basis of phosphorylation-induced activation of the NADPH oxidase. Cell 113:343-355.

Grosskreutz Y, Hermann A, Kins S, Fuhrmann JC, Betz H, Kneussel M (2001) Identification of a gephyrin-binding motif in the GDP/GTP exchange factor collybistin. Biol Chem 382:1455-1462.

Guex N, Peitsch MC (1997) SWISS-MODEL and the Swiss-PdbViewer: an environment for comparative protein modeling. Electrophoresis 18:2714-2723.

Habets GG, Scholtes EH, Zuydgeest D, van der Kammen RA, Stam JC, Berns A, Collard JG (1994) Identification of an invasion-inducing gene, Tiam-1, that encodes a protein with homology to GDP-GTP exchangers for Rho-like proteins. Cell 77:537-549.

Handford CA, Lynch JW, Baker E, Webb GC, Ford JH, Sutherland GR, Schofield PR (1996) The human glycine receptor $\beta$ subunit: primary structure, functional characterisation and chromosomal localisation of the human and murine genes. Mol Brain Res 35:211-219.

Harvey RJ, Thomas P, James CH, Wilderspin A, Smart TG (1999) Identifi- cation of an inhibitory $\mathrm{Zn}^{2+}$ binding site on the human glycine receptor $\alpha 1$ subunit. J Physiol (Lond) 520:53-64.

Karolchik D, Baertsch R, Diekhans M, Furey TS, Hinrichs A, Lu YT, Roskin KM, Schwartz M, Sugnet CW, Thomas J, Weber RJ, Haussler D, Kent WJ (2003) The UCSC genome browser database. Nucl Acids Res 31:51-54.

Kavran JM, Klein DE, Lee A, Falasca M, Isakoff SJ, Skolnik EY, Lemmon MA (1998) Specificity and promiscuity in phosphoinositide binding by pleckstrin homology domains. J Biol Chem 273:30497-30508.

Kawasaki Y, Senda T, Ishidate T, Koyama R, Morishita T, Iwayama Y, Higuchi O, Akiyama T (2000) Asef, a link between the tumor suppressor APC and G-protein signaling. Science 289:1194-1197.

Kins S, Betz H, Kirsch J (2000) Collybistin, a newly identified brain-specific GEF, induces submembrane clustering of gephyrin. Nat Neurosci 3:22-29.

Kirsch J, Langosch D, Prior P, Littauer UZ, Schmitt B, Betz H (1991) The 93-kDa glycine receptor-associated protein binds to tubulin. J Biol Chem 266:22242-22245.

Kirsch J, Kuhse J, Betz H (1995) Targeting of glycine receptor subunits to gephyrin-rich domains in transfected human embryonic kidney cells. Mol Cell Neurosci 6:450-461.

Kneussel M, Betz H (2000) Clustering of inhibitory neurotransmitter receptors at developing postsynaptic sites, the membrane activation model. Trends Neurosci 23:429-435.

Kneussel M, Hermann A, Kirsch J, Betz H (1999a) Hydrophobic interactions mediate binding of the glycine receptor $\beta$-subunit to gephyrin. J Neurochem 72:1323-1326.

Kneussel M, Brandstatter JH, Laube B, Stahl S, Müller U, Betz H (1999b) Loss of postsynaptic $\mathrm{GABA}_{\mathrm{A}}$ receptor clustering in gephyrin deficient mice. J Neurosci 19:9289-9297.

Kneussel M, Engelkamp D, Betz H (2001a) Distribution of transcripts for the brain-specific GDP/GTP exchange factor collybistin in the developing mouse brain. Eur J Neurosci 13:487-492.

Kneussel M, Brandstatter JH, Gasnier B, Feng G, Sanes JR, Betz H (2001b) Gephyrin-independent clustering of postsynaptic $\mathrm{GABA}_{\mathrm{A}}$ receptor subtypes. Mol Cell Neurosci 17:973-982.

Levi S, Logan SM, Tovar KR, Craig AM (2004) Gephyrin is critical for glycine receptor clustering but not for the formation of functional GABAergic synapses in hippocampal neurons. J Neurosci 24:207-217.

Liu Q, Berry D, Nash P, Pawson T, McGlade CJ, LiSS (2003) Structural basis for specific binding of the Gads SH3 domain to an RxxK motif-containing SLP-76 peptide: a novel mode of peptide recognition. Mol Cell 11:471-481.

MacKay DJ, Hall A (1998) Rho GTPases. J Biol Chem 273:20685-20688.

Mammoto A, Sasaki T, Asakura T, Hotta I, Imamura H, Takahashi K, Matsuura Y, Shirao T, Takai Y (1998) Interactions of drebrin and gephyrin with profilin. Biochem Biophys Res Commun 243:86-89.

Manser E, Loo TH, Koh CG, Zhao ZS, Chen XQ, Tan L, Tan I, Leung T, Lim L (1998) PAK kinases are directly coupled to the PIX family of nucleotide exchange factors. Mol Cell 1:183-192.

Meier J, De Chaldee M, Triller A, Vannier C (2000) Functional heterogeneity of gephyrins. Mol Cell Neurosci 16:566-577.

Menéndez C, Otto A, Igloi G, Nick P, Brandsch R, Schubach B, Bottcher B, Brandsch R (1997) Molybdate-uptake genes and molybdopterinbiosynthesis genes on a bacterial plasmid-characterization of MoeA as a filament-forming protein with adenosine triphosphatase activity. Eur J Biochem 250:524-531.

Prior P, Schmitt B, Grenningloh G, Pribilla I, Multhaup G, Beyreuther K, Maulet Y, Werner P, Langosch D, Kirsch J, Betz H (1992) Primary structure and alternative splice variants of gephyrin, a putative glycine receptor-tubulin linker protein. Neuron 8:1161-1170.

Rees MI, Lewis TM, Vafa B, Ferrie C, Corry P, Muntoni F, Jungbluth H, Stephenson JB, Kerr M, Snell RG, Schofield PR, Owen MJ (2001) Compound heterozygosity and nonsense mutations in the $\alpha 1$ subunit of the inhibitory glycine receptor in hyperekplexia. Hum Genet 109:267-270.

Rees MI, Lewis TM, Kwok JB, Mortier GR, Govaert P, Snell RG, Schofield PR, Owen MJ (2002) Hyperekplexia associated with compound heterozygote mutations in the $\beta$ subunit of the human inhibitory glycine receptor (GLRB). Hum Mol Genet 11:853-860.

Rees MI, Harvey K, Ward H, White JH, Evans IL, Duguid IC, Hsu CCH, Coleman SL, Baer K, Waldvogel H, Gibbon F, Smart TG, Owen MJ, Harvey RJ, Snell RG (2003) Isoform heterogeneity of the human gephy- 
rin gene (GPHN), binding domains to the glycine receptor and mutation analysis on hyperekplexia. J Biol Chem 278:24688-24696.

Reid T, Bathoorn A, Ahmadian MR, Collard JG (1999) Identification and characterization of hPEM-2, a guanine nucleotide exchange factor specific for Cdc42. J Biol Chem 274:33587-33593.

Sabatini DM, Barrow RK, Blackshaw S, Burnett PE, Lai MM, Field ME, Bahr BA, Kirsch J, Betz H, Snyder SH (1999) Interaction of RAFT-1 with gephyrin required for rapamycin-sensitive signaling. Science 284:1161-1164.

Schmitt B, Knaus P, Becker C-M, Betz H (1987) The $\mathrm{M}_{\mathrm{r}} 93,000$ polypeptide of the postsynaptic glycine receptor complex is a peripheral membrane protein. Biochemistry 26:805-811.

Schrag JD, Huang W, Sivaraman J, Smith C, Plamondon J, Larocque R, Matte A, Cygler M (2001) The crystal structure of Escherichia coli MoeA, a protein from the molybdopterin synthesis pathway. J Mol Biol 310:419-431.

Schwarz G, Schrader N, Mendel RR, Hecht HJ, Schindelin H (2001) Crystal structures of human gephyrin and plant Cnxl G domains: comparative analysis and functional implications. J Mol Biol 312:405-418.

Schweizer C, Balsiger S, Bluethmann H, Mansuy IM, Fritschy JM, Mohler H, Lüscher B (2003) The $\gamma 2$ subunit of $\mathrm{GABA}_{\mathrm{A}}$ receptors is required for maintenance of receptors at mature synapses. Mol Cell Neurosci 24:442-450.

Sola M, Kneussel M, Heck IS, Betz H, Weissenhorn W (2001) X-ray crystal structure of the trimeric $\mathrm{N}$-terminal domain of gephyrin. J Biol Chem 276:25294-25301.

Triller A, Cluzeaud F, Pfeiffer F, Betz H, Korn H (1985) Distribution of glycine receptors at central synapses: an immunoelectron microscopy study. J Cell Biol 101:683-688.

Vergouwe MN, Tijssen MA, Shiang R, van Dijk JG, al Shahwan S, Ophoff RA, Frants RR (1997) Hyperekplexia-like syndromes without mutations in the GLRA1 gene. Clin Neurol Neurosurg 99:172-178.

Wherlock M, Mellor H (2002) The Rho GTPase family: a Racs to Wrchs story. J Cell Sci 115:239-240.

Worthylake DK, Rossman KL, Sondek J (2000) Crystal structure of Racl in complex with the guanine nucleotide exchange region of Tiam1. Nature 408:682-688.

Xiang S, Nichols J, Rajagopalan KV, Schindelin H (2001) The crystal structure of Escherichia coli MoeA and its relationship to the multifunctional protein gephyrin. Structure 9:299-310. 